\title{
ANTIOXIDANT CAPACITY, BIOACTIVE COMPOUNDS IN COFFEE PULP AND IMPLEMENTATION IN THE PRODUCTION OF INFUSIONS
}

\author{
Stephania Rosales Delgado ${ }^{\bowtie}$, Andres F. Alzate Arbelaez, Benjamín Rojano \\ Science Faculty, National University of Colombia at Medellín (Universidad Nacional de Colombia Sede Medellín) \\ Street 65 \#59A-110, 050034 Medellín, Antioquia, Colombia
}

\begin{abstract}
Background. The main by-product of the coffee production chain is pulp; if it is not properly disposed of, it represents a serious environmental problem. Some studies suggest that this pulp can be used as a source of important compounds. The aim of this study was to evaluate the content of bioactive compounds present in coffee pulps and also to prepare a functional drink-type infusion to propose an alternative use of this by-product.

Material and methods. In coffee pulps (Coffea arabica, var. Colombia and Caturra), the effect of the temperature and the extraction type over the content of total polyphenols, total flavonoids, condensed tannins and phenolic acids were determined. Moreover, the antioxidant activity by ABTS, ORAC and FRAP methodologies. With the best pulp, an infusion-type hot drink was prepared at $80^{\circ} \mathrm{C}$. Finally, sensory assessment was performed.

Results. The best conditions to perform the metabolite extraction were room temperature and $\mathrm{HCl} 1 \%$. The highest trapping capacity of the cationic radical ABTS $^{+*}$ was $24782.93 \mu \mathrm{mol}$ Trolox Equivalent per $100 \mathrm{~g}$ of pulp, ORAC $57087.82 \mu \mathrm{mol}$ Trolox Equivalent per $100 \mathrm{~g}$ of pulp and FRAP $806.93 \mathrm{mg}$ of ascorbic acid equivalent per $100 \mathrm{~g}$ of pulp. For the infusion preparation, two drying methods were used - stove and lyophilization, and overall the best results correspond to the infusions prepared with the lyophilized plant material. This material also had good overall scores in the sensory test (3.51 to 4.04 on a scale of 1 to 5) been the taste most appreciated by the panelists.

Conclusion. The bioactive compound concentration and the antioxidant activity of the coffee pulp suggest that waste can be used as a raw material for the preparation of functional foods, because the values found are similar or greater than those found in other drinks and fruits consumed commercially.
\end{abstract}

Keywords: coffee beans, coffee waste, functional food, polyphenols

\section{INTRODUCTION}

Coffee is currently one of the most popular beverages in the world, constituting $75 \%$ of the non-alcoholic beverages market (Toci et al., 2016). It was discovered 2000 years ago in Ethiopia and since then has commonly been consumed at social events, to improve performance at work and in search of general well-being. The type of drink and the preparation is intimately related to the social and cultural habits of each country where it is consumed (Stefanello et al., 2019). Coffea arabica and Coffea canephora (variety Robusta),

Funding Source Declaration. Universidad Nacional de Colombia.

${ }^{\bowtie}$ srosalesd@unal.edu.co, https://orcid.org/0000-0002-9229-8427 
better known as Arabica and Robusta respectively, are the most important agronomic species. It should be noted that $70 \%$ of coffee production worldwide uses Arabica as its raw material, and this is grown mainly in Central America.

In Colombia, it is the only species that is cultivated throughout the national territory. The seed is covered by several layers, and obtaining this generates different by-products that, when improperly disposed, are a source of contamination, to the level of approximately 15 million tons worldwide (Kovalcik et al., 2018). One of the by-products that has not yet been given a technical or sustainable use is the pulp, which is obtained in the mechanical depulping of the cherry when it is obtained using the wet process (skin and pulp). Coffee cherries contain about $43 \%$ pulp. Of the annual production of 15 million tons of waste, 8.5 million of tons are pulp, which must be properly disposed of or used as raw material in other production processes (Bakker, 2013). Some of the alternatives for its reuse include fertilizers, cattle feed, compost, mushroom cultivation (Heeger et al., 2017).

With regard to composition, it is known that it changes according to the coffee variety and the cultivation zone. It consists of proteins (9-11\%), lipids (2-17\%), cellulose (13-27\%), tannins (4.5\%), pectic materials $(6.5 \%)$, reducing sugars $(12.4 \%)$, nonnitrogenous materials (57-63\%), and caffeine (1.3\%) (Pleissner et al., 2016). Some studies have also found polyphenolic compounds such as Flavan-3-ols (monomers and procyanidins), hydroxycinnamic acids, flavonoids (epicatechin, catechin), flavonoles, and anthocyanidins (Ascencion et al., 2004). These findings suggest that coffee pulp could be used as a source of antioxidants and phenolic compounds. Its use in the food industry would solve an environmental problem, as well as proposing a novel source of bioactive compounds.

The revaluation of waste through the preparation of beverages has been studied for another coffee byproduct, the silver skin. Researchers have found that an infusion prepared with this by-product played an important role in preventing the accumulation of adipose tissue (Rodríguez-Durán et al., 2014). These researchers indicate that the use of food industry byproducts as functional ingredients is one of the main focuses of the field of research and innovation in the food sector. The aim of this study was to determine the antioxidant capacity and the content of antioxidant metabolites of the Colombian coffee pulp of two varieties (Caturra and Colombia), and its application for the production of a functional drink.

\section{MATERIALS AND METHODS}

\section{Reagents}

Fluorescein, 2,2'-Azobis(2-amidinopropane) dihydrochloride (AAPH), 2,4,6-tripyridyl-s-triazine (TPTZ), 2,2-diphenyl-2-picrylhydrazyl free radical (DPPH), 2,2'-azino-bis(3-ethylbenzothiazoline-6-sulphonic acid) diammonium salt (ABTS), gallic acid, 6-hydroxy-2,5,7,8-tetramethylchroman-2-carboxylic acid (Trolox) were purchased from Sigma-Aldrich (St. Louis, Missouri, USA). Methanol, ethanol, $n$-hexane, acetic acid, nitric acid, Folin-Ciocalteu reagent, sodium carbonate, sodium phosphate dibasic, sodium phosphate monobasic, ammonium sulfate, sulfuric acid, potassium persulfate, sodium acetate, hydrochloric acid, and ferric chloride hexahydrate were purchased from Merck (Darmstadt, Germany). In all experiments water type I was used, and all the reagents used in this study were of analytical grade.

\section{Obtaining of coffee pulps}

The coffee pulps were obtained by manual pulping of two varieties of Coffea arabica: var. Caturra and var. Colombia, harvested in Nariño-Colombia, the cultivation area is located at an altitude of $2108 \mathrm{~m}$ a.s.l., average temperature of $20^{\circ} \mathrm{C}$ and relative humidity of $85 \%$. The harvesting of the cherries was carried out in November 2018, and once the pulps had been obtained, they were stored at $-20^{\circ} \mathrm{C}$ until analysis.

\section{Evaluation of extraction methods}

To determine if an acid $\mathrm{pH}$ of the medium would influence the extraction of metabolites and the antioxidant activity, two extraction media were tested, water and a solution of $\mathrm{HCl} 1 \%(\mathrm{pH} 1.80 \pm 0.05)$. For the sample preparation, approximately $25 \mathrm{~g}$ of pulp were weighed and homogenized using an Ultraturrax (Ika-werk, Staufen, Germany), with $60 \mathrm{~mL}$ of extraction solvent (water or $\mathrm{HCl} 1 \%$ ), then centrifuged at $3000 \mathrm{rpm}$ for 5 minutes at room temperature. The supernatant obtained was used for the subsequent analyses. 


\section{Evaluation temperature effect}

In order to evaluate the thermal stability of coffee pulp bioactive compounds, the variety with the best preliminary results was selected and processed to be subjected to heating for 30 minutes at $40,50,60,70$ and $90^{\circ} \mathrm{C}$.

\section{Determination of bioactive compounds}

Total polyphenolic content. The total phenolic content was determined using the Folin-Ciocalteau colorimetric method (Singleton and Rossi, 1965). In a test tube, $50 \mu \mathrm{L}$ of samples were mixed with Folin-Ciocalteau reagent $125 \mu \mathrm{L}$ and $425 \mu \mathrm{L}$ of sodium carbonate solution $(7.1 \% \mathrm{w} / \mathrm{v})$. The final volume was adjusted to $1 \mathrm{~mL}$ with distilled water. The reaction was kept in the dark for 60 minutes; afterwards, the absorbance intensity at $760 \mathrm{~nm}$ was determined using a Multiskan Spectrum spectrophotometer (Thermo-Scientific, Waltham, MA, USA) instrument. A standard curve was made using gallic acid. The results were expressed in $\mathrm{mg}$ of gallic acid equivalents per $100 \mathrm{~g}$ of coffee pulp (mg GAE/100 g).

Total flavonoid content. The method used was proposed by Corrales-Bernal et al. (2015) with some modifications. In a test tube $100 \mu \mathrm{L}$ of the sample was mixed with $30 \mu \mathrm{L}$ of $5 \% \mathrm{NaNO}_{2}(\mathrm{w} / \mathrm{v}), 30 \mu \mathrm{L}$ of $\mathrm{AlCl}_{3}$ $10 \%(\mathrm{w} / \mathrm{v}), 200 \mu \mathrm{L}$ of $\mathrm{NaOH} 1 \mathrm{M}$ and water necessary to adjust it to $1000 \mu \mathrm{L}$, after which the spectrophotometric reading was taken at $510 \mathrm{~nm}$ in a Multiskan Spectrum spectrophotometer and compared with the standard curve using $(+)$-catechin as the standard. The results were expressed in $\mathrm{mg}$ of catechin equivalents per $100 \mathrm{~g}$ of coffee pulp (mg CAE/100 g).

Condensed tannins content. This method is based on the reaction of tannin-condensed compounds with vanillin in an acid medium (Zapata et al., 2013). In brief, $230 \mu \mathrm{L}$ of the sample was added to $670 \mu \mathrm{L}$ of vanillin $(1 \mathrm{~g} / 100 \mathrm{~mL}$ in sulfuric acid $70 \%)$, the mixture was incubated at room temperature for 15 minutes, after which a spectrophotometric reading was performed at $500 \mathrm{~nm}$ in a Multiskan Spectrum spectrophotometer and compared with the standard curve using $(+)$-catechin as the standard. The results were expressed in $\mathrm{mg}$ of catechin equivalents per $100 \mathrm{~g}$ of coffee pulp (mg CAE/100 g).
Phenolics acid content. The content of chlorogenic acid, $p$-coumaric acid, caffeic acid and ferulic acid was determined by HPLC analysis, according to the modified protocol outlined by Kelebek at al. (2009). Prior to injection into the chromatograph, the extract was filtered (pore size $0.45 \mu \mathrm{m}$ ), a liquid chromatograph (LC-20AD, Shimadzu, Kyoto, Japan) was used, equipped with a SIL-20/HT auto injector, a CBM-20 communication module and SPD-M20A photodiode array detector (PDA), at $280 \mathrm{~nm}$. An aqueous C18 ultra column $(5 \mu \mathrm{m}$ in particle size, $250 \mathrm{~mm}$ in length and $4.6 \mathrm{~mm}$ in diameter, Merck) was the stationary phase. The mobile phase was methanol acidified with $0.1 \%$ formic acid, and the flow rate of the mobile phase was $1.0 \mathrm{~mL} / \mathrm{min}, 45^{\circ} \mathrm{C}$ and isocratic conditions. The UV-visible spectrum was swept along $200 \mathrm{~nm}$ to $600 \mathrm{~nm}$ for all peaks. The identification and quantification of the compounds was made with calibration curves for each phenolic acid. The results were expressed in mg of each acid per $100 \mathrm{~g}$ of coffee pulp $(\mathrm{mg} / 100 \mathrm{~g})$.

Total anthocyanin content. To determine anthocyanin content the differential $\mathrm{pH}$ method was used, measuring the absorbance at 530 and $700 \mathrm{~nm}$ in buffers at $\mathrm{pH} 1.0$ and 4.5, the expression $\mathrm{A}=[(\mathrm{A} 530-\mathrm{A} 700)$ pH1.0 - (A530 - A700) pH 4.5] was used and cyanidin-3-glucoside with a molar extinction coefficient of 26900 as a reference compound. The results were expressed as mg equivalents of cyanidin-3-glucoside per $100 \mathrm{~g}$ of coffee pulp (mg C3G/100 g) (Lee et al., 2005).

\section{Determination of caffeine}

The caffeine content was quantified using HPLC, following the method proposed by Shrestha at al. (2016) with some modifications. A liquid chromatograph (Shimadzu) and an ultra-aqueous C18 column (5 $\mu \mathrm{m}$ in particle size, $250 \mathrm{~mm}$ in length and $4.6 \mathrm{~mm}$ in diameter, Merck). The mobile phase was methanol:water (60:40), flow rate $1.0 \mathrm{~mL} / \mathrm{min}$, with an injection volume of $10 \mu \mathrm{L}$, temperature of $40^{\circ} \mathrm{C}$, retention time 2.66 minutes and $275 \mathrm{~nm}$. The results were expressed as $\mathrm{mg}$ of caffeine per $100 \mathrm{~g}$ of coffee pulp $(\mathrm{mg} / 100 \mathrm{~g})$ (Rahim et al., 2014). 


\section{Antioxidant capacity determinations}

Radical cationic assay $\mathrm{ABTS}^{\cdot+}$. $\mathrm{ABTS}^{++}$was generated throughout oxidation of ABTS induced by ammonium persulfate in a phosphate buffer at $\mathrm{pH} 7.4$ (Re et al., 1999). For this methodology, the ability of the sample to trap the $\mathrm{ABTS}^{\cdot+}$ cation radical was evaluated, and to perform the assay the decrease in the absorbance at $732 \mathrm{~nm}$, read after $30 \mathrm{~min}$ of reaction, was tested. In brief, $10 \mu \mathrm{L}$ of sample was added to $990 \mu \mathrm{L}$ of an $\mathrm{ABTS}^{++}$solution. Antioxidant activity was determined by comparison with Trolox (employed as a standard compound). The results were reported as $\mu \mathrm{mol}$ of Trolox equivalents per $100 \mathrm{~g}$ of coffee pulp $(\mu \mathrm{mol} \mathrm{TE} / 100 \mathrm{~g})$.

\section{Ferric reducing antioxidant power (FRAP) assay.}

This method evaluates the reducing power of a sample based on its ability to reduce ferric iron $\left(\mathrm{Fe}^{+3}\right)$ complexed with 2,4,6-tri(2-pyridyl)-s-triazine (TPTZ) to ferrous form $\left(\mathrm{Fe}^{+2}\right)$, this presents a maximum of absorbance at a wavelength between $590-595 \mathrm{~nm}$, according to Griffin and Bhagooli (2004). For the analysis, $50 \mu \mathrm{L}$ of the sample and $900 \mu \mathrm{L}$ of a solution of acetic acidsodium acetate buffer ( $\mathrm{pH} 3.4$ ), TPTZ, $\mathrm{FeCl}_{3}$, in a ratio of 10:1:1 was mixed. After 30 minutes of reaction, the absorbance was read at $593 \mathrm{~nm}$, and the value was compared with the reference curve constructed with ascorbic acid as the standard. The results were expressed as $\mathrm{mg}$ of ascorbic acid equivalent antioxidant capacity per $100 \mathrm{~g}$ of coffee pulp (mg AEAC/100 g).

\section{Oxygen radical absorbance capacity ORAC assay.} With this method, the ability of the samples to inhibit the oxidation of the fluorescein (fluorescent probe) induced by the peroxyl radical $\left(\mathrm{ROO}^{\circ}\right)$ was evaluated, using the method described by Prior at al. (2005). An aliquot of $30 \mu \mathrm{L}$ of the sample was added to $21 \mu \mathrm{L}$ of fluorescein $1 \times 10^{-2} \mathrm{M}, 2899 \mu \mathrm{L}$ of phosphate buffer $75 \mathrm{mM} \mathrm{pH} 7.4$, and $50 \mu \mathrm{L}$ of AAPH $0.6 \mathrm{M}$, and the temperature of the reaction was controlled at $37 \pm 0.2^{\circ} \mathrm{C}$. The analysis was conducted in a LS55 Fluorescence Spectrometer (Perkin Elmer, Waltham, Massachusetts, USA), with excitation at $493 \mathrm{~nm}(10 \mathrm{~nm}$ slit $)$ and emission at $515 \mathrm{~nm}(15 \mathrm{~nm}$ slit) and attenuator of $1 \%$. The protective effect of the sample was calculated using the differences of area under the decay curve of the fluorescein between the blank (reaction without sample) and the sample, and the result was compared with the curve of the Trolox as the antioxidant standard. The results were reported as $\mu \mathrm{mol}$ of Trolox equivalents per $100 \mathrm{~g}$ of coffee pulp ( $\mu \mathrm{mol} \mathrm{TE} / 100 \mathrm{~g})$, according to the following equation:

$$
\mathrm{ORAC}=\frac{\mathrm{AUC}-\mathrm{AUC}^{\circ}}{\mathrm{AUC}^{\circ}{ }_{\text {Trolox }-\mathrm{AUC}^{\circ}}} f \text { Trolox }
$$

where:

AUC - the area under the curve of the sample,

$\mathrm{AUC}^{\circ}$ - the area under the curve for the control,

$\mathrm{AUC}_{\text {Trolox }}$ - the area under the curve for the Trolox,

$f$ - the ratio between Trolox and sample concentrations.

\section{Coffee pulp infusion preparation}

The coffee pulp was dried using two methods: an oven at $70^{\circ} \mathrm{C}$ for 7 hours and lyophilization. The dry material was pulverized using a mill (Ika-A11), and the infusions were prepared by the immersion of bags with $1.6 \mathrm{~g}$ of powdered pulp in $250 \mathrm{~mL}$ of water at $80^{\circ} \mathrm{C}$ for 7 minutes. The samples were stored at $-20^{\circ} \mathrm{C}$ until analysis. The infusion was analyzed for its content of total polyphenols, tannins, caffeine and the antioxidant capacity by ABTS and ORAC.

\section{Sensory evaluation of the infusions}

In order to determine whether the prepared drink would be publicly accepted, hedonic proof was carried out by a paired preference test and an acceptability test using a 5-point scale where taste, smell and general appearance were evaluated in the beverages. The test was performed by 100 untrained panelists, who assessed $20 \mathrm{~mL}$ of the beverages at approximately $60^{\circ} \mathrm{C}$.

\section{Statistical analysis}

All the experiments were performed in triplicate. The statistical differences were calculated with a $95 \%$ significance level $(p<0.05)$, using the Statgraphics Plus version 5.0 program (Statistical Graphics Corp., Rockville, MD). To evaluate preference for the two infusions a paired preference test was carried out. In order to establish if there were statistically significant differences, the $Z$ test of proportions was used, which uses the area under the normal probability curve to estimate the probability of opportunities in the results of each of the samples, with the equation: 


$$
Z=\frac{X-N p-0.5}{\sqrt{N p q}}
$$

where:

$X$ - the number of preference responses,

$N$ - the total number of trials,

$p$ - probability of choosing the preferred sample $(0.5)$,

$q=1-p=0.5$. A $Z$-score $<1.96$ provides sufficient evidence in favor of the null hypothesis.

For the comparison of the evaluation of each of the attributes between the two samples, the SPSS statistics software was used to perform a goodness-of-fit test and to verify the normality of the data. Based on the results, it was decided to perform a non-parametric test, (Mann-Whitney U test) for independent samples with a 0.05 significance level.

\section{RESULTS AND DISCUSSION}

Table 1 and Figure 1 summarize the metabolite content and the antioxidant activity obtained in the two coffee pulp varieties prepared in water and in acid water $(\mathrm{HCl} 1 \%)$ respectively; in general, the acidity of the medium had a positive effect both for extraction yield and antioxidant activity expression. The content of total polyphenols, flavonoids, condensed tannins, also ORAC and FRAP values were up to $56 \%$ higher in acid water.

The total polyphenol content in the extracts of coffee pulp found in this study range from 254.62$453.21 \mathrm{mg} \mathrm{GAE} / 100 \mathrm{~g}$ of pulp; the highest value is for the Caturra variety $-\mathrm{HCl} 1 \%$. The results were compared with other residues, white grape skin and onion peel (239 and $422 \mathrm{mg}$ GAE/100 g) (Makris et al., 2007), being similar to those found in this work in the aqueous and acidified preparations respectively; in coffee epicarp Herrera Rincon (2016) reported a content of $0.796 \mathrm{mg} \mathrm{GAE} / 100 \mathrm{~g}$, ours being up to 500 times higher. With regard to the flavonoid content (132.61-784.76 mg CAE/100 g), the highest value corresponds to the preparation made with the Caturra variety in acidic water, the aqueous extracts of the two varieties are statistically similar; the values found in acid medium are similar to those reported by Makris et al. (2007) for other residues such as apple peel and olive tree leaves 566 and $858 \mathrm{mg} \mathrm{CAE} / 100 \mathrm{~g}$ respectively, with those found in this work surpassed only by red grape pulp of $2349 \mathrm{mg} \mathrm{CAE} / 100 \mathrm{~g}$.

The condensed tannin content $(13.59-97.07 \mathrm{mg}$ $\mathrm{CAE} / 100 \mathrm{~g}$ ) and anthocyanins (3.64 and $4.09 \mathrm{mg}$ $\mathrm{C} 3 \mathrm{G} / 100 \mathrm{~g}$ ) was compared with that reported by other authors who studied different kind of by-products and extraction methodologies. It was found that those obtained in this research were relatively minor. Norbey

Table 1. Content of antioxidant metabolites in Coffea arabica pulps

\begin{tabular}{|c|c|c|c|c|}
\hline \multirow{2}{*}{$\begin{array}{l}\text { Metabolite } \\
\mathrm{mg} / 100 \mathrm{~g} \text { of pulp }\end{array}$} & \multicolumn{2}{|c|}{ Caturra variety } & \multicolumn{2}{|c|}{ Colombia variety } \\
\hline & water & $\mathrm{HCl} 1 \%$ & water & $\mathrm{HCl} 1 \%$ \\
\hline Total polyphenols & $254.6^{\mathrm{a}} \pm 3.5$ & $453.2^{\mathrm{d}} \pm 3.2$ & $284.1^{c} \pm 6.5$ & $424.0^{\mathrm{d}} \pm 3.2$ \\
\hline Total flavonoids & $132.6^{\mathrm{a}} \pm 9.0$ & $784.8^{\mathrm{b}} \pm 2.6$ & $139.1^{\mathrm{a}} \pm 1.2$ & $654.3^{\mathrm{c}} \pm 4.3$ \\
\hline Condensed tannins & $13.6^{\mathrm{a}} \pm 3.9$ & $94.4^{\mathrm{b}} \pm 8.3$ & $15.5^{\mathrm{a}} \pm 8.5$ & $97.1^{\mathrm{b}} \pm 8.7$ \\
\hline Total anthocyanins & $0.00 \pm 0.00$ & $4.09 \pm 2.90$ & $0.00 \pm 0.00$ & $3.64 \pm 1.00$ \\
\hline Chlorogenic acid & $0.00 \pm 0.00$ & $8.84^{c} \pm 0.05$ & $5.62^{b} \pm 0.05$ & $5.52^{\mathrm{b}} \pm 0.05$ \\
\hline Caffeic acid & $0.00 \pm 0.00$ & $19.81^{\mathrm{c}} \pm 0.05$ & $13.41^{\mathrm{b}} \pm 0.05$ & $20.79^{c} \pm 0.05$ \\
\hline$p$-Coumaric acid & $0.00 \pm 0.00$ & $7.95^{\mathrm{b}} \pm 0.05$ & $5.77^{\mathrm{c}} \pm 0.05$ & $8.92^{\mathrm{d}} \pm 0.05$ \\
\hline Ferulic acid & $0.00 \pm 0.00$ & $7.26^{b} \pm 0.05$ & $5.10^{c} \pm 0.05$ & $8.57^{\mathrm{d}} \pm 0.05$ \\
\hline
\end{tabular}

Results are expressed as mean \pm standard deviation; the letters on the superscripts indicate significant differences $(p<0.05)$. 
(A) - ORAC

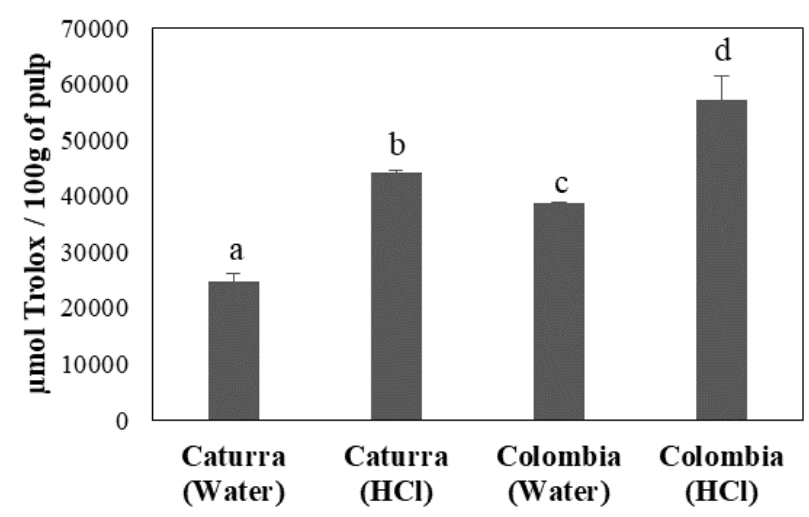

(B) - ABTS

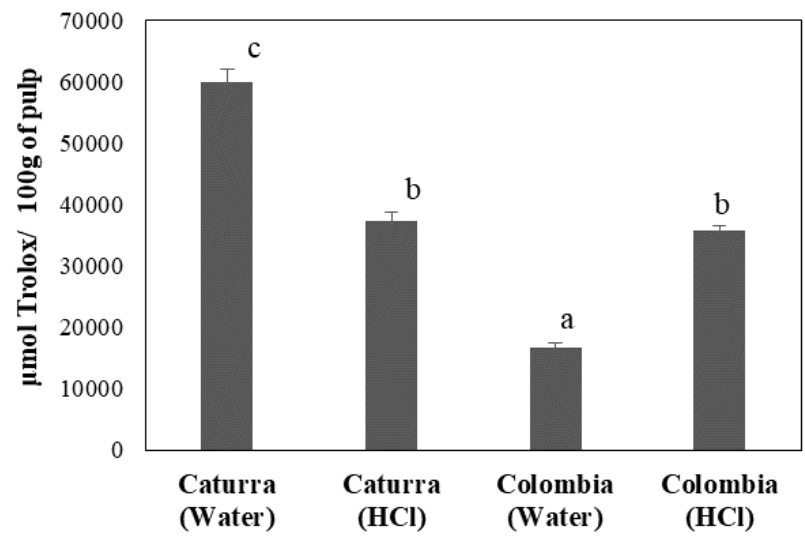

(C) - FRAP

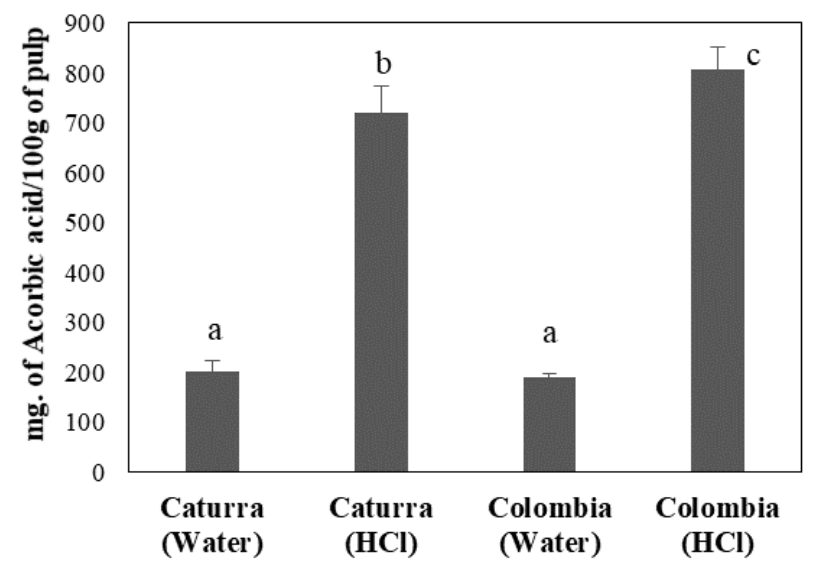

Fig. 1. Antioxidant activity of coffee pulp: ORAC value (panel A), ABTS assay (panel B) and FRAP assay (panel C)
(2015) reported condensed tannin concentrations of $1824.91 \mathrm{mg} \mathrm{C} 3 \mathrm{G} / 100 \mathrm{~g}$ of pulp; on the other hand, the anthocyanin content in Brazilian coffee pulp found by Prata and Oliveira (2007) was $20.04 \mathrm{mg} \mathrm{C} 3 \mathrm{G} / 100 \mathrm{~g}$. It should be noted that no organic solvents were used in the processing of the samples in this study, which contribute to the extraction of this type of metabolite.

Concerning the hydroxycinnamic acid content, the results were similar to those observed in the other antioxidant metabolites; the highest values were always found in the acidulated extracts; the content of chlorogenic acid in the coffee pulp of the present study (5.52$8.84 \mathrm{mg} / 100 \mathrm{~g}$ of pulp) was lower than that reported in spent coffee grounds (176.8 mg/100 g) (Cortes Meza et al., 2017); this acid is commonly found in coffee in its commercial presentation, which is prepared from the roasted seed. It is possible that the roasting process facilitates the extraction. In less processed coffee samples, such as green coffee, Moon et al. (2009) found similar concentrations of $5.30 \mathrm{mg} / 100 \mathrm{~g}$. The hydroxycinnamic acid found in greater proportion was caffeic acid (13.41-20.79 mg/100 g of pulp), which is the concentration in the aqueous extract similar to those found in another Colombian coffee pulp (13.70 $\mathrm{mg} / 100 \mathrm{~g}$ of pulp) (Norbey, 2015). The content of ferulic acid and $p$-coumaric acid were similar to those reported by Norbey (2015) in Colombian coffee pulp (17.79 and $1.36 \mathrm{mg} / 100 \mathrm{~g}$ of pulp).

\section{Antioxidant activity of coffee pulp}

There are several reported methods for the estimation of antioxidant activity, and these are classified according to the action mechanism of the antioxidant; the HAT (hydrogen atom transfer) mechanism is based on the transfer of a hydrogen atom evaluated in techniques such as ORAC, and the SET (single electron transfer) mechanism consists in the transfer of an electron, measured in techniques such as DPPH, ABTS and FRAP (Huang et al., 2005).

The ORAC value and FRAP were significantly higher in the acid extracts, $57087.8 \mu \mathrm{mol} \mathrm{TE} / 100 \mathrm{~g}$ pulp and $806.93 \mathrm{mg} \mathrm{AEAC} / 100 \mathrm{~g}$ of pulp, respectively. Both correspond to the acid extract of the Colombia variety. Generally, the polyphenolic compounds contribute significantly to the antioxidant activity of the food: in the case of coffee pulp, FRAP had a strong correlation with the flavonoid content with 
a correlation coefficient $\left(R^{2}\right)$ of 0.9301 and the ORAC values (57 $087.8 \mu \mathrm{mol} \mathrm{TE} / 100 \mathrm{~g}$ pulp) were very well related to the tannin content $\left(R^{2}\right)$ of 0.6935 . These results are supported by the evidence of many studies on antioxidant activity in vitro and in vivo, which show the action mechanism of flavonoids, including the ability to scavenger free radicals, chelate metal ions and inhibit oxidases. In addition, they can increase the availability of endogenous antioxidants, as well as the activity of antioxidant enzymes, and inhibitors of enzymes involved in the generation of ROS (radical oxygen species) (Trueba, 2003). On the other hand, condensed tannins, are effective scavengers of free radicals, which inhibit the oxidation of tissues. It has been demonstrated that condensed tannins have a preference to neutralize exogenous species, as well as the ability to act as non-competitive inhibitors of the enzyme xanthine oxidase, one of the major generators of free radicals in cellular metabolism (Xia et al., 1996).

\section{Effect of acidification of the extraction}

The extraction of metabolites and antioxidant activity were significantly higher in the solutions prepared in an acid medium. These results may be due to the fact that polyphenolic compounds have a maximum absorption between 200 and $360 \mathrm{~nm}$. The band at the smallest wavelength is known as band B, while the band at the longest wavelength is known as band $\mathrm{C}$; these bands move at longer wavelengths, depending on the nature of the solvents, electron extraction, and electron donating substituents. Friedman and Jürgens (2000) report higher absorptivity values (from 0.7 to $1 \mathrm{~nm}$ ) at $\mathrm{pH} 1$ for various polyphenols that decrease with increasing $\mathrm{pH}$. Similarly, Chethan and Malleshi (2007) found that the content of polyphenols in the extracts of African millet decreased as the $\mathrm{pH}$ became alkaline, with notable changes in their absorption models. The authors postulate that the chemical structure of phenolic compounds has a profound effect on susceptibility to $\mathrm{pH}$ changes, since it can affect and change the ionization state of the molecules and therefore their maximum absorbance. A consequence of the structural changes of polyphenols is the oxidation of these molecules. Therefore, the result of a lower capacity of reducing agent measured by the FRAP method in the aqueous extracts may be due to the oxidation of the polyphenols present in the medium. These results agree with those reported by Amendola et al. (2010). These authors report that at a $\mathrm{pH}$ between 3 and 5 grape extracts maintained their reducing capacity, while at a $\mathrm{pH}$ between 7 and 9 there was a progressive loss of antioxidant capacity of the samples.

\section{Effect of temperature on bioactive extraction}

The sample that was selected to evaluate the effect of temperature on the content of bioactive compounds and the antioxidant activity was the acidulated extract of the Colombian variety, because it presented greater global results in the first part of this study. Analyses of the most remarkable metabolites (total phenols, flavonoids and hydroxycinnamic acids) and antioxidant activity measured by ORAC and ABTS were performed, the results of which are summarized in Figure 2.

Several authors agree that heating a food or vegetable sample improves the solubility, dilution coefficient, and the solvent diffusivity. However, above a certain temperature some bioactive compounds can degrade. As shown in Figure 2, the exposition of the sample at different temperatures affected both the metabolite content and antioxidant capacity; the flavonoid content of the sample decreases with respect to the control, but it remains constant in the range of $40^{\circ} \mathrm{C}$ to $70^{\circ} \mathrm{C}$. Finally, at $90^{\circ} \mathrm{C}$ there is an increase. The content of total polyphenols decreases significantly between $50^{\circ} \mathrm{C}$ and $70^{\circ} \mathrm{C}$, while at $90^{\circ} \mathrm{C}$ the concentration is similar to that found in the control. Regarding hydroxycinnamic acids, it was found that at $90^{\circ} \mathrm{C}$ all the values were below the detectable limit of the technique, suggesting their thermal susceptibility at these temperatures, with $p$-coumaric and ferulic being the most sensitive acids: even at $70^{\circ} \mathrm{C}$, its quantification was not possible. The increase in the concentration of some metabolites when the temperature was increased is in agreement with that reported by several authors, who shows that the performance in the extraction of compounds is directly proportional to the temperature, or leads to a concentration of the sample (Pinelo et al., 2005).

The antioxidant activity measured in both techniques (ABTS and ORAC) decreased significantly even with a slight increase in temperature. This fact can be attributed to the deleterious effect of temperature over the bioactive compounds, so that despite temperature favoring solubility and diffusion, at the 


\section{A - Total polyphenols and flavonoids}

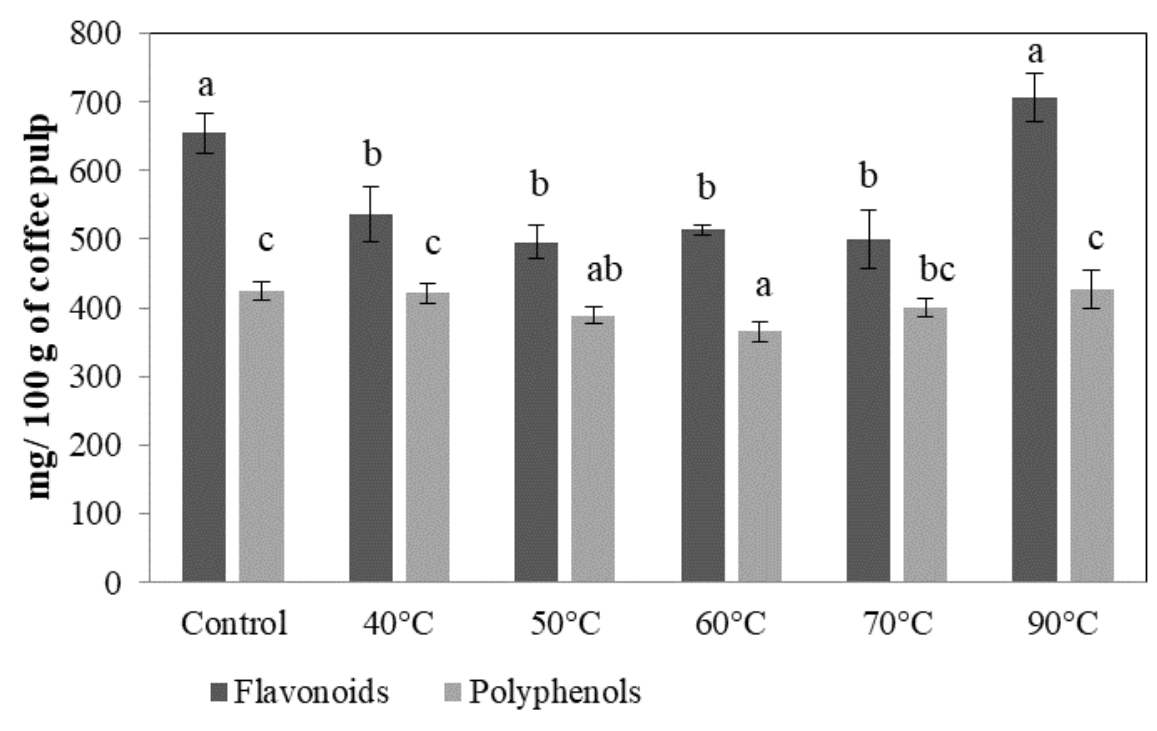

\section{B - Antioxidant activity by ORAC and ABTS}

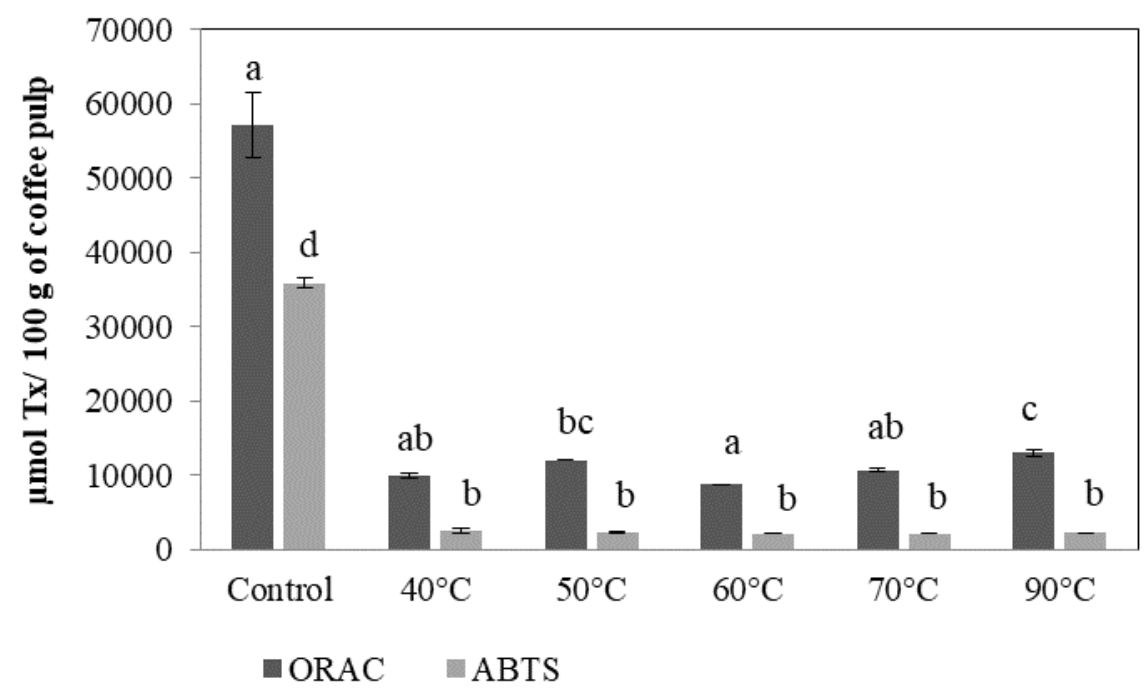

Fig. 2. Effect of temperature in the antioxidant compounds (panel $\mathbf{A}$ ) and antioxidant capacity (panel B) of coffee pulps

same time thermal destruction occurs (Vongsangnak et al., 2004). From the results obtained in this investigation, it is possible to affirm that phenolic compounds with a high antioxidant capacity present in coffee pulp are thermolabile. It should be noted that a high content of polyphenolic compounds is not necessarily related to high antioxidant capacity, because the antioxidant activity of the extract may also be influenced by the structure and interaction of other phenolic compounds (Cacace and Mazza, 2003). 
Rosales Delgado, S., Alzate Arbelaez, A. F., Rojano, B. (2019). Antioxidant capacity, bioactive compounds in coffee pulp and implementation in the production of infusions. Acta Sci. Pol. Technol. Aliment., 18(3), 235-248. http://dx.doi.org/10.17306/J. AFS.2019.0663

Table 2. Metabolites and antioxidant activity of the Coffea arabica pulp infusions

\begin{tabular}{lcccc}
\hline \multicolumn{1}{c}{ Analysis } & Caturra dried & Caturra liophylized & Colombia dried & Colombia liophylized \\
\hline $\begin{array}{l}\text { Total polyphenols } \\
\text { mg GAE/L }\end{array}$ & $123.9^{\mathrm{a}} \pm 5.1$ & $182.1^{\mathrm{b}} \pm 3.6$ & $128.7^{\mathrm{a}} \pm 2.7$ & $209.2^{\mathrm{c}} \pm 6.0$ \\
$\begin{array}{l}\text { Condensed tannins } \\
\text { mg CAE/L }\end{array}$ & $12.2^{\mathrm{b}} \pm 0.5$ & $9.7^{\mathrm{a}} \pm 1.1$ & $23.4^{\mathrm{c}} \pm 1.7$ & $12.4^{\mathrm{ab}} \pm 1.4$ \\
$\begin{array}{l}\text { Caffeine content } \\
\mathrm{mg} / \mathrm{L}\end{array}$ & $56.60^{\mathrm{a}} \pm 0.05$ & $77.68^{\mathrm{c}} \pm 0.05$ & $53.21^{\mathrm{a}} \pm 0.05$ & $101.49^{\mathrm{b}} \pm 0.05$ \\
$\begin{array}{l}\text { ABTS } \\
\mu \mathrm{mol} \mathrm{Tx} / \mathrm{L}\end{array}$ & $3057.9^{\mathrm{c}} \pm 189.9$ & $1940.3^{\mathrm{d}} \pm 18.0$ & $2270.9^{\mathrm{a}} \pm 144.6$ & $3965.1^{\mathrm{b}} \pm 194.4$ \\
$\begin{array}{l}\text { ORAC } \\
\mu \mathrm{mol} \mathrm{Tx} / \mathrm{L}\end{array}$ & $4855.4^{\mathrm{c}} \pm 330.4$ & $8649.6^{\mathrm{d}} \pm 816.1$ & $14807.6^{\mathrm{a}} \pm 71.7$ & $12436.6^{\mathrm{b}} \pm 5.5$ \\
\hline
\end{tabular}

The results are reported for a liter of infusion. All values are shown as the mean \pm standard deviation $(n=3)$. The letters on the superscripts indicate significant differences $(p<0.05)$.

\section{Preparation of coffee pulp beverage type-infusion}

Due to the promising results obtained in the coffee pulp, an infusion-type beverage was prepared. For its preparation, the pulp of the two coffee varieties analyzed in the first part was used; the drying process was carried out using a drying oven and lyophilization, and the results obtained in the beverages are summarized in Table 2 and reported per liter of the infusion.

The total polyphenol content in the infusion was between 123.95 and $209.19 \mathrm{mg} \mathrm{GAE} / \mathrm{L}$, the highest values were found in the lyophilized samples, the Colombian variety being the one with the highest content. Furthermore, the two varieties dried with the stove method had statistically similar values. These results agree with those found in the first part, ie. the phenolic compounds present in the coffee pulp are thermolabile. It was therefore expected that the stove drying method had a negative effect, while in lyophilization these compounds were preserved, because this method removes the water content of the sample without using an increase in temperature. The content of phenols in the infusions was lower than that reported in coffee in its traditional presentation (3430 mg GAE/L) (Heeger et al., 2017). However, it is similar to that reported by Giao et al. (2007). In infusions prepared with 48 plants considered as medicinal, the authors found an average content of total polyphenols of $239.26 \mathrm{mg}$ $\mathrm{GAE} / \mathrm{L}$, which is similar to the coffee pulp infusion, and which is superior to that of traditionally consumed infusions, such as chamomile (196 mg GAE/L) and bay leaf (167 mg GAE/L).

The condensed tannin content was evaluated in the infusion, because these are responsible for the roughness, dryness and bitterness of the coffee. In addition, they have been proposed as excellent antioxidant molecules, whose consumption in small doses helps with immunomodulation and enzymatic activity (Chung et al., 2010). Regarding its content in the drink, it was found that the Colombian variety, dried using the stove method, was the largest (23.41 mg CAE/L). On the other hand, lyophilized samples were significantly smaller and statistically similar. This result is similar to that reported by Díaz et al. (2018) in roasted coffee. The authors found that a longer roasting time for the grain significantly increased the concentration of tannins in the drink. It should be noted that the concentrations of condensed tannins found in a coffee pulp infusion are similar to those reported by the same authors for coffee prepared with medium grain roasting for 5-7 min.

Caffeine is an alkaloid group of xanthines. A bitter taste and stimulant for its non-selective antagonist action of adenosine receptors is found mainly in coffee and tea (Baelo et al., 2011). Given its importance at a biological and economic level, it was decided to evaluate the caffeine concentration in the infusion. The concentrations found are between 53.21 
and $101.49 \mathrm{mg} / \mathrm{L}$; the highest content was found in the freeze-dried Colombia variety, while the samples dried in the oven showed no significant differences. The concentration range of this alkaloid in coffee is wide, from $174-5400 \mathrm{mg} / \mathrm{L}$ (the values change according to variety, climate and processing). In spite of the fact that the caffeine in the pulp infusion is lower, its value is significant and suggests a promising alternative for a moderate consumption of the alkaloid. It should be noted that the results are similar to those found in decaffeinated coffee $(110 \mathrm{mg} / \mathrm{L})$ (McCusker et al., 2006).

For the antioxidant activity measured by ABTS and ORAC, comparable behaviors were found. In both techniques the highest values are for the Colombian variety, but differ in the fact that in the ABTS test a higher value was found in the prepared infusion with lyophilized pulp, while in the ORAC analysis the peroxyl radical trapping capacity was higher in the ovendried sample. As for ABTS, it presented a good correlation with the content of total polyphenols (0.9648), suggesting that these types of compounds are responsible for the cationic radical trapping capacity when comparing the values of the infusion with a beverage prepared from coffee pulp. In a study performed by Heeger et al. (2017), the value of $3020 \mu \mathrm{mol} \mathrm{TE} / \mathrm{L}$ was found, which is very similar to the one found in this investigation in the lyophilized Caturra variety (3057.89 TE/L). In addition, the results found are up to 30 times higher in the infusion than those reported by Ludwig et al. (2012) in espresso coffee. On the other hand, ORAC values were found in the range between 4855.44-14756.94 $\mu \mathrm{mol} \mathrm{TE} / \mathrm{L}$; the highest value found was in the Colombia oven-dried variety, which presented the highest concentration of condensed tannins. The ORAC results were comparable to those reported by Naranjo et al. (2011) for different Colombian coffees. The authors report values between 9955.9 and $12224.6 \mu \mathrm{mol}$ of TE/L of coffee. The values found in the infusions are within this range and even 1.2 times higher.

In general terms, the results show that the infusion prepared with coffee pulp is a viable alternative for the reuse of this by-product, since its implementation would not only solve the environmental problem that its inadequate disposition represents, but also offer a food alternative with a remarkable antioxidant activity, which could, in some consumer markets, replace all or part of the traditional coffee drink.

\section{Sensory test}

In order to know if the infusion would be acceptable in the market, a sensory test was carried out using 100 untrained panelists who gave answers in a survey, where $\mathrm{AB}$ is the lyophilized Caturra variety infusion and BA is the lyophilized Colombia variety infusion. These samples were chosen based on the global results of the previous section. To determine if a preference exists for either of the two samples evaluated, a paired preference test was carried out.

The results of the $Z$-test of proportions show that of a total of 100 untrained panelists, 47 said that prefer $\mathrm{AB}$ and $53 \mathrm{BA}$.

Replacing in the equation we obtain that the $Z$ value 0.5 , and using a table of values of the accumulated probability below $Z$, we find that the probability for this value of $Z$ is $0.3085(1-0.6915)$ and therefore a $Z$ -score $=0.1915$. This value is much lower than 1.96; this means there is sufficient evidence in favor of the null hypothesis, and therefore it is concluded that there are no statistically significant differences in the overall preference of either of the two products.

Although the overall evaluation of the beverage indicated that there were no significant differences between the two varieties, we proceeded to establish statistically significant differences in each of the attributes evaluated in the beverages: taste, smell and general appearance.

To proceed with the comparison, first it was necessary to establish whether the behavior of the data had a normal distribution. For this, SPSS statistics software was used with a goodness-of-fit test using the Kolmogorov-Smirnov test (KS) for which it is proposed as Ho: the data analyzed follow a normal distribution pattern, with a level of significance of 0.05 .

In all the parameters evaluated in the drink, it was found that when the KS test was performed, the level of significance is much lower than the $P$ value established (0.05). Therefore the null hypothesis is rejected and it is concluded that the results of the sensory analysis in terms of taste, smell and appearance of the infusions of the two varieties do not have a normal distribution. 


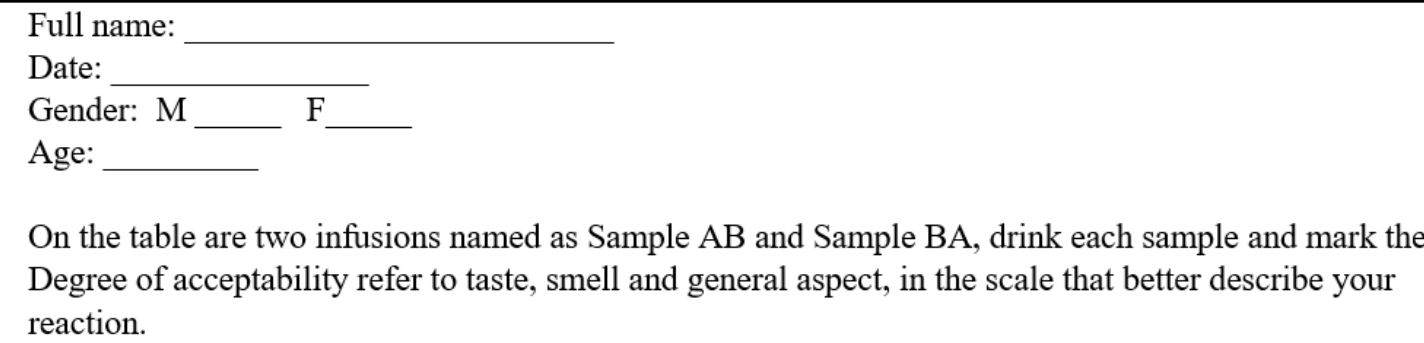

\begin{tabular}{|c|c|c|c|c|c|c|}
\hline & \multicolumn{3}{|c|}{ Sample: $\underline{\mathrm{AB}}$} & \multicolumn{3}{|c|}{ Sample: $\underline{\mathrm{BA}}$} \\
\hline Degree of acceptability & Taste & Smell & Aspect & Taste & Smell & Aspect \\
\hline I like very much & & & & & & \\
\hline I like it a little bit & & & & & & \\
\hline I do not like or dislike & & & & & & \\
\hline I dislike a little & & & & & & \\
\hline I dislike it a lot & & & & & & \\
\hline Observations & & & & & & \\
\hline
\end{tabular}

Indicate with an $\mathrm{X}$ which of the two samples was your favorite $\mathrm{AB}$ : BA: THANKS!

Fig. 3. Survey conducted in the sensory analysis

Due to the fact that the data did not present a normal distribution, a nonparametric test was used to compare them: Mann-Whitney U test for independent samples with a level of significance of 0.05 , and is posited as Ho: taste or smell or appearance of the two drinks are equal. These results are summarized in the table.

For the three evaluated attributes it was found that the difference between the calculated and established significance is greater than zero, and therefore the null hypothesis is accepted in all cases. It is concluded that the pulp infusions of the two varieties are statistically equal in terms of taste, smell and general appearance.

Radial charts were also used to show the results of the sensory evaluation. It should be noted that although there were no statistically significant differences

Table 3. Goodness-of-fit test of sensory analysis results

\begin{tabular}{lccccc}
\hline \multicolumn{1}{c}{ Attribute } & Sample & Mean & Standard deviation & Significance & Normal distribution \\
\hline Taste & AB & 3.83 & 1.03529 & $2.56 \cdot 10^{-16} \approx 0$ & NO \\
& BA & 4.04 & 0.92025 & $2.22 \cdot 10^{-17} \approx 0$ & NO \\
\multirow{3}{*}{ Smell } & AB & 3.51 & 1.03957 & $2.43 \cdot 10^{-15} \approx 0$ & NO \\
& BA & 3.56 & 1.03787 & $4.35 \cdot 10^{-10} \approx 0$ & NO \\
General aspect & AB & 3.89 & 0.94168 & $1.07 \cdot 10^{-12} \approx 0$ & NO \\
& BA & 3.80 & 0.93203 & $7.19 \cdot 10^{-15} \approx 0$ & NO \\
\hline
\end{tabular}



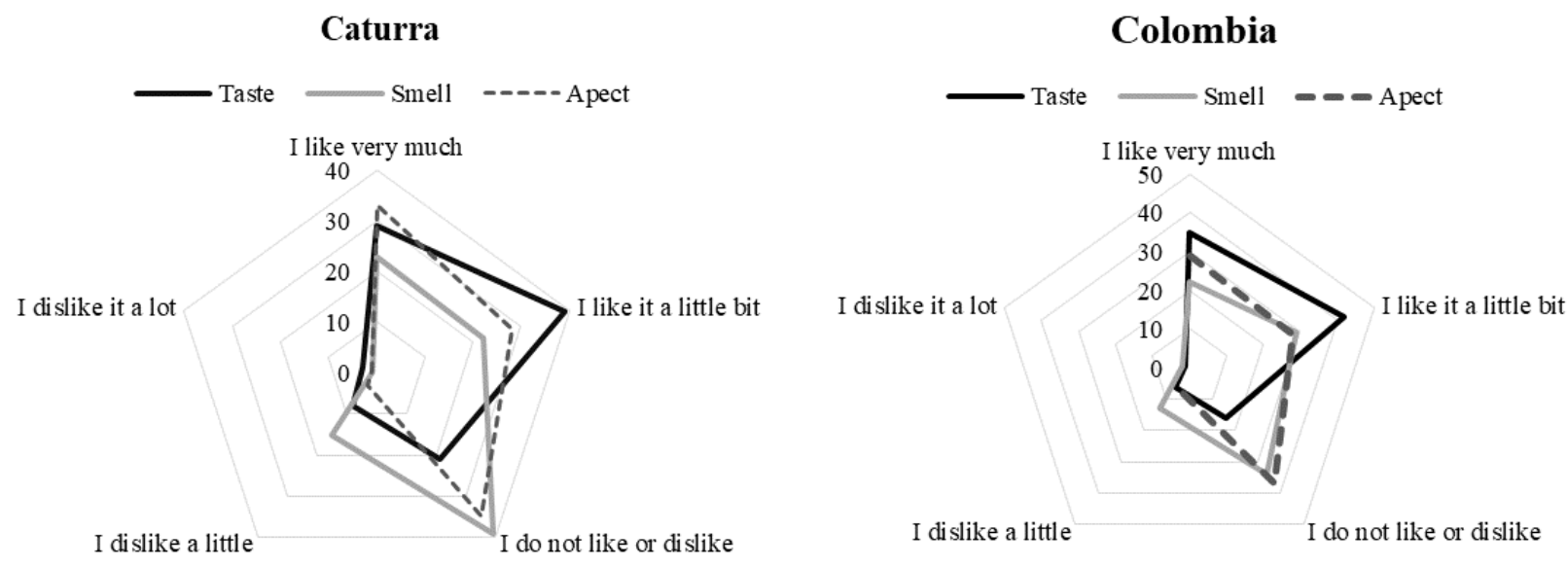

Fig. 4. Radial chart of taste, smell and general appearance of the infusions

Table 4. U Mann-Whitney test

\begin{tabular}{lccc}
\hline Atribute & Calculated significance & Calculated significance - established significance & Significant differences \\
\hline Taste & 0.161 & 0.111 & NO \\
Smell & 0.648 & 0.595 & NO \\
Aspect & 0.465 & 0.415 & NO \\
\hline
\end{tabular}

between the aspects evaluated in the drink, it had an outstanding global evaluation, on a scale of 1 to 5 values average obtained by the infusion are between 3.51 and 4.04, with the taste being the most appreciated by the panelists, and the smell the least prominent. The valuations in the attributes are close to the descriptive of "I like very much", "I like it a little bit", "I do not like or dislike", "I dislike a little", "I dislike it a lot". The only aspect to be "disliked" was smell, and this may be because coffee pulp is not a raw material that is commonly used for the preparation of infusions, but has potential to be such.

\section{CONCLUSIONS}

The metabolite concentration and antioxidant activity found in the coffee pulp of the two coffee varieties studied was significant and comparable with other agroindustrial residues and even with commercial products. The results suggest that this matrix could be used as a functional food. The acidification of the extraction medium had a positive overall effect on extraction performance and activity. As regards the temperature, although the extraction was somewhat facilitated, the increase in temperature this had a deleterious effect, therefore it follows that the compounds present in the pulp are thermolabile. The infusions prepared with the pulp of lyophilized coffee were assessed positively by the public in terms of acceptability, suggesting that its implementation as a hot drink could be a viable and promising alternative method for reusing this waste. It also presents important metabolite content with antioxidant activity, which represents a healthy alternative to coffee consumption, along with a significant concentration of tannins and caffeine.

\section{ACKNOWLEDGEMENTS}

This project was financially supported by the Office of Research Management of the Universidad Nacional de Colombia, Medellín, Colombia. The authors are grateful for the help of TECNOPARQUE node Medellín (Laura Cristina Rojas M.Sc.) on extraction methodologies. 
Rosales Delgado, S., Alzate Arbelaez, A. F., Rojano, B. (2019). Antioxidant capacity, bioactive compounds in coffee pulp and implementation in the production of infusions. Acta Sci. Pol. Technol. Aliment., 18(3), 235-248. http://dx.doi.org/10.17306/J. AFS.2019.0663

\section{REFERENCES}

Alean, J., Chejne, F., Rojano, B. (2016). Degradation of polyphenols during the cocoa drying process. J. Food Eng., 189, 99-105. https://doi.org/10.1016/j. jfoodeng.2016.05.026

Amendola, D., Faveri, D. M. De, Spigno, G. (2010). Grape marc phenolics : Extraction kinetics, quality and stability of extracts. J. Food Eng., 97(3), 384-392. https://doi. org/10.1016/j.jfoodeng.2009.10.033

Ascencion, M., Ramirez-Coronel Marnet, N., Kolli, V. S. K., Roussos, S., Guyot, S., Augur, C. (2004). Characterization and estimation of proanthocyanidins and other phenolics in coffee pulp (Coffea arabica) by thiolysis-high-performance liquid chromatography. J. Agric. Food Chem., 52(5), 1344-49. https://doi.org/10.1021/ jf035208t

Baelo, C. U., Carmen, G. M., Pozas Tormo, R., López, Á. B. (2011). Algunos principios activos del café, del té y del cacao (pp. 16-19). http://www.geocities.ws/quimesca/ articulos/principios.pdf

Bakker, R. R. C. (2013). Availability of lignocellulosic feedstocks for lactic acid production. Food \& Biobased Research Wageningen UR, Report 139.

Cacace, J. E., Mazza, G. (2003). Mass transfer process during extraction of phenolic compounds from milled berries. J. Food Eng., 59, 379-389. https://doi.org/10.1016/ S0260-8774(02)00497-1

Chethan, S., Malleshi, N. G. (2007). Finger millet polyphenols: Optimization of extraction and the effect of $\mathrm{pH}$ on their stability. Food Chem., 105, 862-870. https://doi. org/10.1016/j.foodchem.2007.02.012

Chung, K., Wong, T. Y., Wei, C., Huang, Y., Lin, Y. (2010). Tannins and human health: A review. Crit. Rev. Food Sci. Nutr., 38, 6, 421-464. https://doi. org/10.1080/10408699891274273

Corrales-Bernal, A., Vergara, A. I., Rojano, B., Yahia, E., Maldonado, M. E. (2015). Características nutricionales y antioxidantes de la uchuva colombiana (Physalys peruviana L.) en tres estadios de su maduración. Arch. Latinoam. Nutr., 65(4), 254-262.

Cortes Meza, S., Ortiz, A., Ramirez, L. S. (2017). Determinación de antioxidante en subproductos de café producido y comercializado en Risaralda (Colombia). Pereira: Universidad Tecnológica de Pereira. Retrieved from: http://repositorio.utp.edu.co/dspace/bitstream/ handle $/ 11059 / 7597 / 63373$ C828.pdf?sequence $=1$

Díaz, F., Ormaza, A. M., Rojano, B. A. (2018). Efecto de la tostión del café sobre el perfil de taza, contenido de compuestos antioxidantes y la actividad antioxidante. Inf. Tecnol., 29(3), 31-42. https://doi.org/10.4067/ s0718-07642018000300187

Friedman, M., Jürgens, H. S. (2000). Effect of pH on the stability of plant phenolic compounds. J. Agric. Food Chem., 48(6), 2101-10. http://dx.doi.org/10.1021/ jf990489j

Giao, M., Gonzales, M., Rivero, M., Pereira, C., Pintado, M., Malcata, X. (2007). Infusions of Portuguese medicinal plants: Dependence of final antioxidant capacity and phenol content on extraction features. J. Sci. Food Agric., 87(14), 2638-47. http://dx.doi.org/10.1002/ jsfa. 3023

Griffin, S. P., Bhagooli, R. (2004). Measuring antioxidant potential in corals using the FRAP assay. J. Exp. Marine Biol. Ecol., 302(2), 201-211. https://doi.org/10.1016/j. jembe.2003.10.008

Heeger, A., Kosińska-Cagnazzo, A., Cantergiani, E., Andlauer, W. (2017). Bioactives of coffee cherry pulp and its utilisation for production of Cascara beverage. Food Chem., 221, 969-975. https://doi.org/10.1016/j. foodchem.2016.11.067

Herrera Rincon, F. R. (2016). Obtención de antioxidantes a partir del epicarpio de café (Coffea arabica L.) Empleando fluidos presurizados, una alternativa de aprovechamiento para este residuo agroindustrial. Bogotá: Universidad Libre, Facultad de Ingeniería.

Huang, D., Ou, B., Prior, R. L. (2005). The chemistry behind antioxidant capacity assays. Agric. Food Chem., 53(6), 1841-1856. https://doi.org/10.1021/jf030723c

Kelebek, H., Selli, S., Canbas, A., Cabaroglu, T. (2009). HPLC determination of organic acids, sugars, phenolic compositions and antioxidant capacity of orange juice and orange wine made from a Turkish cv. Kozan. Microchem. J., 91(2), 187-192. https://doi.org/10.1016/j. microc.2008.10.008

Kovalcik, A., Obruca, S., Marova, I. (2018). Valorization of spent coffee grounds: A review. Food Bioprod. Proc., 110, 104-119. https://doi.org/10.1016/j.fbp.2018.05.002

Lee, J., Durst, R. W., Wrolstad, R. E. (2005). Determination of total monomeric anthocyanin pigment content of fruit juices, beverages, natural colorants, and wines by the $\mathrm{pH}$ differential method: collaborative study. J. AOAC Int., 88(5), 1269-1278.

Ludwig, I. A., Sanchez, L., Caemmerer, B., Kroh, L. W., De Peña, M. P., Cid, C. (2012). Extraction of coffee antioxidants: Impact of brewing time and method. Food Res. Int., 48(1), 57-64. https://doi.org/10.1016/j. foodres.2012.02.023 
Rosales Delgado, S., Alzate Arbelaez, A. F., Rojano, B. (2019). Antioxidant capacity, bioactive compounds in coffee pulp and implementation in the production of infusions. Acta Sci. Pol. Technol. Aliment., 18(3), 235-248. http://dx.doi.org/10.17306/J. AFS.2019.0663

Makris, D. P., Boskou, G., Andrikopoulos, N. K. (2007). Polyphenolic content and in vitro antioxidant characteristics of wine industry and other agri-food solid waste extracts. J. Food Comp. Anal., 20(2), 125-132. https:// doi.org/10.1016/j.jfca.2006.04.010

McCusker, R. R., Fuehrlein, B., Goldberger, B. A., Gold, M. S., Cone, E. J. (2006). Caffeine content of decaffeinated coffee. J. Anal. Toxicol., 30(8), 611-613. https://doi. org/10.1093/jat/30.8.611

Moon, J. K., Hyui Yoo, S. U. N., Shibamoto, T. (2009). Role of roasting conditions in the level of chlorogenic acid content in coffee beans: Correlation with coffee acidity. J. Agric. Food Chem., 57(12), 5365-5369. https://doi. org/10.1021/jf900012b

Naranjo, M., Vélez, L. T., Rojano, B. A. (2011). Actividad antioxidante de café colombiano de diferentes calidades [Antioxidant activity of different grades of Colombian coffee]. Rev. Cubana Plant. Med., 16(2), 164-173.

Norbey, T. A. (2015). Extracción asistida por ultrasonido de compuestos fenólicos de la pulpa de café (Coffea arabica L.) variedad Castillo. Corporación Universitaria Lasallista.

Pinelo, M., Rubilar, M., Jerez, M., Sineiro, J., Nuñez, M. J. (2005). Effect of solvent, temperature , and solvent-tosolid ratio on the total phenolic content and antiradical activity of extracts from different components of grape pomace. J. Agric. Food Chem., 53,6, 2111-2117. https:// doi.org/10.1021/jf0488110

Pleissner, D., Neu, A. K., Mehlmann, K., Schneider, R., Puerta-Quintero, G. I., Venus, J. (2016). Fermentative lactic acid production from coffee pulp hydrolysate using Bacillus coagulans at laboratory and pilot scales. Biores. Technol., 218, 167-173. https://doi.org/10.1016/j. biortech.2016.06.078

Prata, E. R. B. A., Oliveira, L. S. (2007). Fresh coffee husks as potential sources of anthocyanins. LWT - Food Sci. Technol., 40(9), 1555-1560. https://doi.org/10.1016/j. lwt.2006.10.003

Prior, R. L., Wu, X., Schaich, K. (2005). Standardized methods for the determination of antioxidant capacity and phenolics in foods and dietary supplements. J. Agric. Food Chem., 53, 10, 4290-4302. https://doi. org/10.1021/jf0502698

Rahim, A. A., Nofrizal, S., Saad, B. (2014). Rapid tea catechins and caffeine determination by HPLC using microwave-assisted extraction and silica monolithic column. Food Chem., 147, 262-268. https://doi.org/10.1016/j. foodchem.2013.09.131
Re, R., Pellegrini, N., Proteggente, A., Pannala, A., Yang, M., Rice-Evans, C. (1999). Antioxidant activity applying an improved ABTS radical cation decolorization assay. Free Rad. Biol. Med., 26(9-10), 1231-1237. https:// doi.org/10.1016/S0891-5849(98)00315-3

Rodríguez-Durán, L. V., Ramírez-Coronel, M. A., Aranda-Delgado, E., Nampoothiri, K. M., Favela-Torres, E., Aguilar, C. N., Saucedo-Castañeda, G. (2014). Soluble and bound hydroxycinnamates in coffee pulp (Coffea arabica) from seven cultivars at three ripening stages. J. Agric. Food Chem., 62(31), 7869-7876. https://doi. org/10.1021/jf5014956

Shrestha, S., Rijal, S. K., Pokhrel, P., Rai, K. P. (2016). A simple HPLC method for the determination of caffeine content in tea and coffee. J. Food Sci. Technol. Nepal, 9, 74. https://doi.org/10.3126/jfstn.v9i0.16200

Singleton, V. L., Rossi, J. A. (1965). Colorimetry of total phenolics with phosphomolybdic-phosphotungstic acid reagents. Am. J. Enol. Viticult., 16(3), 144-158.

Stefanello, N., Spanevello, R. M., Passamonti, S., Porciúncula, L., Bonan, C. D., Olabiyi, A. A., ... Schetinger, M. R. C. (2019). Coffee, caffeine, chlorogenic acid, and the purinergic system. Food Chem. Toxicol., 123, 298-313. https://doi.org/10.1016/j.fct.2018.10.005

Toci, A. T., Farah, A., Pezza, H. R., Pezza, L. (2016). Coffee adulteration: more than two decades of research. Crit. Rev. Anal. Chem., 46(2), 83-92. https://doi.org/10.1080 /10408347.2014.966185

Trueba, G. P. (2003). Los flavonoides: Antioxidantes o prooxidantes. Rev. Cubana Invest. Biomed., 22(1), 48-57.

Vongsangnak, W., Gua, J., Chauvatcharin, S., Zhong, J. (2004). Towards efficient extraction of notoginseng saponins from cultured cells of Panax notoginseng. Biochem. Eng. J., 18, 115-120. https://doi.org/10.1016/ S1369-703X(03)00197-9

Xia, Y., Khatchikian, G., Zweier, J. L. (1996). Adenosine deaminase inhibition prevents free radical-mediated injury in the postischemic heart. J. Biol. Chem., 271(17), 10096-102.

Zapata, K., Cortes, F. B., Rojano, B. A. (2013). Polifenoles y actividad antioxidante del fruto de guayaba agria (Psidium araca) [Polyphenols and antioxidant activity of sour guava fruit (Psidium araca). Inf. Tecnol., 24(5), 103-112. https://doi.org/10.4067/S0718-07642013000 500012 